\title{
Firm survival strategies for entrepreneurs and freelancers in the translation and interpreting sector
}

\section{Gieure, Clara ${ }^{\text {a }}$; Berbegal-Mirabent, Jasmina ${ }^{\text {b }}$}

${ }^{\mathrm{a}}$ Department of Education, Universidad Católica de Valencia, Spain, ${ }^{\mathrm{b}}$ Department of Economy and Business Organisation, Universitat Internacional de Catalunya, Spain.

\begin{abstract}
This study examines a set of factors that contribute to firm and self-employed survival in the Spanish translation and interpreting sector (henceforth, T\&I). In the midst of a global downturn firm and self-employed survival is key for the progress of economies and for a better and more stable future. The empirical analysis explores different patterns that lead to firm survival. Using comparative qualitative analysis, we identify seven combinations of causal conditions that explain the outcome. This study contributes towards a better understanding of entrepreneurial translators and interpreters' lifespan. The results indicate that entrepreneurs and freelancers can follow different pathways, all of them, conducing to firm survival. With little literature on the topic of firm survival in the T\&I sector, thisstudy aims to fill this gap and make a valuable contribution to the current literature on $T \& I$ firms andself-employed survival.
\end{abstract}

Keywords:firm survival, translation and interpreting, entrepreneur, freelance, self-employed, qualitative comparative analysis 


\section{Introduction}

In the current turbulent and uncertain economic environment, it is of utmost importance to better understand how firms align their resources in their attempt to survive and rapidly scale (Audretsch et al., 2016). As firm creation becomes central for the economic and social development of countries and regions, so it does the duration and survival of those firms. In recent years, scholars have increasingly focused their attention on the entry and exit modes of firms (Carreira\&Teixeira, 2016), the entrepreneurial activity (Acs et al., 2015)or motivation (Solesvik, 2013). However, little attention has been paid to the strategies entrepreneurs follow once a business has been created. Considering that entrepreneurs and freelancers are today one of the principal agents for a prosperous economy (Kressel\& Lento, 2012) and that only about half of all new small businesses survive after 4 years (Cader\& Leatherman, 2011) there is a need to shed new light on how firms perform and what strategies contribute to their success. This paper offers an analysis of survival factors of T\&I firms and self-employed entrepreneurs in Spainaiming at reducing the high levels of unemployment this sector has traditionally experienced and in doing so, contributing to the literature with factors that guarantee firm sustainability. The remainder of this article has the following structure. We first discuss the theoretical backgrounds and present the propositions posed herein. Then, we present the data and method used to empirically analyzethe propositions. Sectionfour develops a model that positsrelationships between all theoretical constructs and presents the results. Section fivepresents our concluding remarks, implications for business owners and limitations.

\section{Theoretical background}

Firm survival is considered the period of time the company stays in business, that is, the duration a business performs in the market (Van Praag, 2003). This metric is essential because it gives an idea of the expertise of the firm in the market, and therefore, combined with other variables it is possible to analyze how different factors have shaped its performance. Literature on firm survival varies depending on the sector. The focus here is the T\&I service sector, known for its long history and for its prosperous market within European institutions where hundreds of translators and interpreters work in a full time basis to meet all the language requirements of the European Commission and other related institutions and agencies. Gouadec (2007) claims that the duration of a firm will depend on its internationalization, technology, specialization, and ultimately, know-how. The T\&I market has abolished distances, having strongly benefited from globalization. On the contrary, it heavily relies on strong investments in translation tools, namely, computeraided programs, and features numerous oral and written specializations. 
Considering the specificities of the T\&I market, the following paragraphs summarize the factors that, according to the literature, may influence firm survival.

Business size. For certain industries, firm size explains productivity and growth. Nevertheless, there is a minimum efficiency size, below which firms are generally destined to fail (Ribeiro-Soriano \& Urbano, 2010). Some academics even suggest that larger firms are more likely to obtain public aid and subsidies (Görg \& Strobl, 2007). This study analyzes small and medium-sized firms andfreelancers, although this is a sector where the freelancers prevail (Gouadec, 2007). Therefore, we pose that:The size of a T\&I firm does not have an influence on the survival of the firm.

Entrepreneurial education. Numerous experts recognize that education and training can enhance business skills. However, although the traditional managerial skills taught in business schools are essential, they are not sufficient. More attention is neededto the development of entrepreneurial skills, attributes and behaviors, which go beyond purely commercial abilities (Kirby 2004). For the purposes of this study, we define entrepreneurial educationas the entrepreneurial knowledge and skills a person acquires when undertaking training and the specific knowledge acquired to start and run a T\&I business. The first type of education aims at training people to undertake and manage a new business, thus learning the basics of venture creation and managerial skills; the latter focuses on gaining particular skills or knowledge applicable to the T\&I sector. Thus, we argue that: If the owner of a T\&I business has received entrepreneurial education before starting a business, this training will have a positive influence on the survival of the firm.

Entrepreneurial background. It is also paramount to consider the effect of having entrepreneurial kith and kin, or even relatives and friends with successful entrepreneurial stories (Kim et al., 2006). In this respect, Gatewood et al. (1995) claimed that entrepreneurs and business owners coming from business family backgrounds enjoy of a greater success than their peers that come from families without such a business background. Mintzberg (2004) also claimed that management skills are gained only through previous experience and stressed the fact that understanding abstract concepts is challenging when there is no understanding of the relationship between those concepts and the real experience. This rationale suggests that any prior experience that takes place before setting up a business could be beneficial for the business. Thus, we posit that: For the business owner, having an entrepreneurial family background has a positive influence on the survival of the firm.

Financial investment. Firm creation involves investing in different resources: knowledgebased, financial, organizational, social capital and intellectual property (Frid at al., 2015). When an entrepreneur has a business opportunity but lacks the resources to exploit it, it is difficult to pursue a business venture. Having access to resources constitutes a key factor in the decision to start a new venture, given that it influences the perception of business 
viability. From the entrepreneur's standpoint, access to capital and financing is therefore a critical issue, particularly for small and medium firms (Verheul \& Thurik, 2001). Accordingly, we suggest that: Investing in a business has a positive influence on the survival of the firm.

Media. The Web 2.0 has evolved to become part of almost every facet of our lives and its many tools benefit both customers and business owners. First, it enables customers to express their feelings and personal thoughts on firms and products to a group of people, and thus, firms have direct access to customers' feedback. Second, the Web 2.0 and its social media tools help businesses expandtheir markets. Today, firms are increasingly aware of the potential of using the media to create brand recognition, generate revenue, gain feedback and insights from customers, and to improve customer relationships (Müllern, 2011). In this study, the term "media" denotes the collective communication outlets or tools that firms useto interact online with the customer. Based on these considerations, we pose that: The use of the media by the business owner has a positive influence on the survival of the firm.

\section{Data and method}

\subsection{Sample and data}

The study considers 46 firms and self-employed entrepreneurs operating in the T\&I sector in Spain. Information was obtainedby directly contacting the owners of these firms, and sending them the link to an online questionnaire. This process took from July to August 2014. The first part of the survey consisted of a set of basic questions to better characterize the profile of each firm and the owner/entrepreneur. In the second part, specific questions concerning the areas of interest outlined in the previous section were formulated.Table 1 displays the main characteristics of the sample under analysis.

Table 1. Descriptive statistics of the sample

\begin{tabular}{|c|c|}
\hline Variables & Descriptives \\
\hline \multirow{2}{*}{ Gender } & $28 \%$ Men \\
\hline & $72 \%$ Women \\
\hline \multirow{2}{*}{ Legal form } & $49 \%$ Freelance \\
\hline & $51 \%$ Other forms \\
\hline \multirow{3}{*}{ Company age } & $37 \%$ Between $0-5$ years \\
\hline & $35 \%$ Between $6-10$ years \\
\hline & $15 \%$ Over 10 years \\
\hline \multirow{3}{*}{$\begin{array}{l}\text { Educational background of } \\
\text { the founder/freelance }\end{array}$} & $41 \%$ Degree in Translation and Interpreting \\
\hline & $12 \%$ English, French and Spanish Studies \\
\hline & $12 \%$ Master's Degree in Translation \\
\hline
\end{tabular}


To explain the outcome, five antecedent conditions grouped in three main dimensionswere considered: human capital, investment, and media. The first dimension, human capital, was operationalized by three antecedent conditions: size of the business, potential experience in starting up a business (either by the owner of the business or someone from his/her family), and entrepreneurial education. The second dimension, considered the importance of receiving external funding for stating-up the business. Lastly, the third dimension referred to the use of social media as a tool for generating awareness of the business activity.

\subsection{Method}

Because we are interested in exploring different patterns that lead to firm survival, in this study we use qualitative comparative analysis (QCA). According to Woodside (2016)this technique overcomes some of the traditional drawbacks of traditional methods as QCA allows identifying which combinations of antecedent conditions leads to a specific outcome by assuming complex causality and focusing on asymmetric relationships. Configurations consist of conditions or factors that can be positive, negative, or absent.

The first step in QCA consists in transforming variables into fuzzy or crisp set terms. Variables with continuous variables can be expressed in fuzzy terms (Ragin, 2008), with values ranging from 0 (full non-membership) to 1 (full membership), and 0.5 denoting the point of maximum ambivalence. For dummy variables, crisp-set is preferred. Table 2 shows how this step, known as calibration, was conducted.

Table 2. Calibration values

\begin{tabular}{|c|c|c|c|c|}
\hline \multirow{2}{*}{\multicolumn{2}{|c|}{ Variable definition }} & \multicolumn{3}{|c|}{ Membership threshold values ${ }^{\text {a }}$} \\
\hline & & $\begin{array}{c}\text { Full non- } \\
\text { membership } \\
(0.05)\end{array}$ & $\begin{array}{c}\text { Crossover } \\
\text { point } \\
(0.5) \\
\end{array}$ & $\begin{array}{c}\text { Full } \\
\text { membership } \\
(0.95)\end{array}$ \\
\hline Outcomes & Firm survival $^{\text {b }}$ & 0 & & 1 \\
\hline \multirow{5}{*}{$\begin{array}{l}\text { Antecedent } \\
\text { conditions }\end{array}$} & Size & 1.1 & 2.9 & 4.1 \\
\hline & Entrepreneurial background $^{\mathrm{b}}$ & 0 & & 1 \\
\hline & Entrepreneurial education $^{\mathrm{b}}$ & 0 & & 1 \\
\hline & Financial investment $^{\mathrm{b}}$ & 0 & & 1 \\
\hline & Media $^{\mathrm{b}}$ & 0 & & 1 \\
\hline
\end{tabular}

a Observations falling in the percentile-90 represent full set membership. Percentile-10 indicates full nonmembership. The crossover point is defined by the median.

${ }^{\mathrm{b}}$ Expressed in crisp-set terms.

Before proceeding with the analysis, it is required to check whether any of the antecedent conditions is necessary. Following Shneiderand Wagemann(2010)a condition is 
"necessary" when its consistency score exceeds the threshold value of 0.9 . The analysis reveals that all values loaded below this cut-off value, except of entrepreneurial education, which consistency score was slightly above 0.9 . However, in the interest of including this variable in the analysis we decided to also include it.

In the following step, the truth table is constructed, and afterwards the number of rows is reduced using Boolean algebra. In this process, the Quine-McCluskey algorithm (Quine, 1952) computes the commonalities among the configurations that yield to the outcome and return the minimum a set of combinations of causal conditions that are sufficient to produce the outcome. The reduction is based on the empirical relevance of the solution (coverage) and the extent to which cases sharing similar conditions exhibit the same outcome (consistency). This study uses the fsQCA software program, in its version 2.5.

\section{Empirical results and discussion}

Table 3 shows the results. Following Ragin's (2008) recommendation, this study reports the intermediate solution. The coding for the solution table follows the approach of Ragin and Fiss (2008), where black circles $(\bullet)$ indicate the presence of a condition, white circles $(O)$ denote its absence, and blank cells represent ambiguous conditions.

Table 3. Sufficient configurations of antecedent conditions for the different outcomes

\begin{tabular}{|c|c|c|c|c|c|c|c|c|}
\hline \multirow[b]{2}{*}{ ن̃ } & \multicolumn{3}{|c|}{ Antecedent conditions } & \multicolumn{4}{|c|}{ Coverage } & \multirow[b]{2}{*}{ 离 } \\
\hline & $\stackrel{\tilde{N}}{\sim}$ & 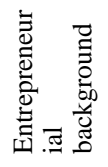 & 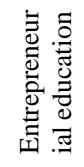 & 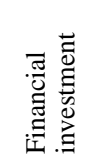 & 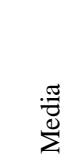 & 竞 & 范 & \\
\hline 1 & O & $\bullet$ & $\bullet$ & & & 0.4021 & 0.1700 & 1.0000 \\
\hline 2 & $\bullet$ & & $\bullet$ & & $\bullet$ & 0.1774 & 0.0948 & 0.9790 \\
\hline 3 & 0 & 0 & & & $\bullet$ & 0.1090 & 0.1005 & 1.0000 \\
\hline 4 & 0 & $\bullet$ & & $\bullet$ & $\bullet$ & 0.2521 & 0.0229 & 1.0000 \\
\hline 5 & $\bullet$ & $\mathrm{O}$ & & $\bullet$ & $\bullet$ & 0.0543 & 0.0133 & 0.9344 \\
\hline 6 & $\bullet$ & $\mathrm{O}$ & $\bullet$ & $\bullet$ & & 0.0648 & 0.0238 & 0.9444 \\
\hline 7 & O & $\mathrm{O}$ & O & $\bullet$ & O & 0.0229 & 0.0229 & 1.0000 \\
\hline $\begin{array}{l}\text { Solu } \\
\text { Freq }\end{array}$ & ra & 298 , & & ncy & 0.9 & 9149 & & \\
\hline
\end{tabular}

Seven different combinations of the antecedent conditions explain the outcome, confirming our initial intuition that there is no unique recipe to explain firm survival. On the contrary, results indicate that entrepreneurs/freelancers can follow different pathways, all of them, 
conducing to firm survival. This finding is of great interest because the profile of the entrepreneurs in this sector that decide to become self-employed is fairly heterogeneous. In terms of the fit of the model, the consistency of all the configurations is above the acceptable cut-off point of 0.8 . Raw coverage values also validate our approach.

Turning to the specific results, we find that the firm size is not a key determinant, meaning that there are different formulas for succeeding in this sector regardless of the size of the firm. As for the effect of the entrepreneurial background of the owner, it seems to play a weak role, but contributes to the outcome when the firm is small. Somehow different is the effect of entrepreneurial education. In three out of seven configurations, it adds value to the firm, signaling that business skills are desirable, particularly when there is a lack of previousentrepreneurial experience or the firm is small.As expected, results indicate that access to financial resources is critical. This effect is accentuatedwhen the owner has no previous entrepreneurial experience. Lastly, the use of media as a way to reach a wider audience and attract customers is also found to positively contribute to the outcome.

Following Ragin's (2008) recommendation, the two causal paths with greater raw coverage (configurations 1 and 4) deserve further attention. Both recipes apply for small firms in which the entrepreneur/owner possesses some kind of entrepreneurial background. Configuration 1 suggests that if under these circumstances the owner has received training on how to start up a business, his/her business activity has chances to be successful in the mid-long term. The absence of entrepreneurial education can be compensated by financial resources (which will provide access to resources) combined with the use of social media to generate firm awareness (configuration 4).

\section{Concluding remarks, implications and limitations}

Aiming at finding which combinations of antecedent conditions guarantee firm sustainability in terms of survival in the T\&I sector, we conducted a qualitative-quantitative study.The contribution of this study to the existing literature is twofold. First, because the survival of firms is necessary for the progress of the economies and knowledge transfer, this research presents a new approach to the study of the determinants of firm survival. Second, the T\&I sector reveals a limited number of related research studies, therefore, this gap should be addressed to provide empirical evidence that help future entrepreneurs to successfully exploit the resources and capabilities they possess when deciding entering the sector.These findings have important implications for T\&Ibusiness owners, but in particular, for start-ups. In this way, firms should make efficient use of the media, financial resources and undertake entrepreneurial training to achieve success.

Despite covering an existing gap in the literature, this study has several limitations that represent unique opportunities for future studies. First, the survey failed to 
differentiatebusiness owners from self-employees, thus, addressing both groups separately would be more informative. Second, because much of the service offered by firms in the T\&I sector can be delivered online, it would also be interesting expanding the sample and analyzing the effect of internal/external customers. Third, although the study uses reliable variables, a need remains to question whether some other variables might be best proxies to capture the outcome. Four, future studies should also consider longitudinal analyses.

\section{References}

Acs, Z. J., Szerb, L., \&Autio, E. (2015). Global entrepreneurship and development index 2014. New York, NY: Springer.

Audretsch, D., Guo, X., Hepfer, A., Menendez, H., \& Xiao, X. (2016).Ownership, productivity and firm survival in China. Economia e PoliticaIndustriale, 1-17.

Cader, H.A., \& Leatherman, J.C. (2011).Small business survival and sample selection bias. Small Business Economics, 37(2), 155-165.

Carreira, C. \&Teixeira, P. (2016) Entry and exit in severe recessions: lessons from the 2008-2013 Portuguese economic crisis. Small Business Economics, 46, 1-27.

Frid, C.J., Wyman, D.M., \& Gartner, W.B. (2015).The Influence of Financial 'Skin in the Game' on New Venture Creation. Academy of Entrepreneurship Journal, 21(2), 1.

Gatewood, E.J., Shaver, K.G., \& Gartner, W.B. (1995).A longitudinal study of cognitive factors influencing start-up behaviors and success at venture creation.Journal of Business Venturing, 10(5), 371-391.

Görg, H., \&Strobl, E. (2007).The effect of R\&D subsidies on private R\&D.Economica, 74(294), 215-234.

Gouadec, D. (2007). Translation as a Profession (Vol. 73).John Benjamins Publishing.

Kim, P.H., Aldrich, H.E., \&Keister, L.A. (2006).Access (not) denied: The impact of financial, human, and cultural capital on entrepreneurial entry in the United States. Small Business Economics, 27(1), 5-22.

Kirby, D.A. (2004). Entrepreneurship education: Can business schools meet the challenge?.Education + Training, 46(8/9), $510-519$.

Kressel, H., \& Lento, T.V. (2012). Entrepreneurship in the Global Economy: Engine for Economic Growth.Cambridge University Press.

Mintzberg, H. (2004). Managers not MBAs.San Francisco: Berrett-Koehler.

Müllern, T. (2011).Facebook as a marketing cannel.A study of eCommerce retailers' Facebook page ambitious. Master Thesis.InternationellaHandelshögskolan, Jönköping, Sweden.

Quine, W.V. (1952). The problem of simplifying truth functions. The American Mathematical Monthly, 59(8), 521-531.

Ragin, C.C. (2008). Redesigning social inquiry: Fuzzy sets and beyond. Chicago: University of Chicago Press.

Ragin, C.C., \&Fiss, P. (2008).Net effects analysis versus configurational analysis: An empirical demonstration.In C.C. Ragin (ed.): Redesigning Social Inquiry: Fuzzy Sets and Beyond (pp. 190-212). Chicago, IL: University of Chicago Press.

Ribeiro-Soriano, D., \& Urbano, D. (2010). Employee-organization relationship in collective entrepreneurship: An overview. Journal of Organizational Change Management, 23(4), 349-359. 
Schneider, C.Q.,\&Wagemann, C. (2010).Standards of good practice in qualitative comparative analysis (QCA) and fuzzy-sets. Comparative Sociology, 9(3), 397-418.

Solesvik, M. Z. (2013). Entrepreneurial motivations and intentions: investigating the role of education major. Education+ Training, 55(3), 253-271.

Van Praag, C.M. (2003). Business survival and success of young small business owners. Small Business Economics, 21(1), 1-17.

Verheul, I. \&Thurik, R. (2001). Start-up capital: Does gender matter?.Small Business Management, 16, 329-345.

Woodside, A.G. (2016). The good practices manifesto: Overcoming bad practices pervasive in current research in business. Journal of Business Research, 69(2), 365-381. 